\title{
Péter Pázmány: Cardinal, Archbishop of Esztergom, Primate of Hungary
}

\author{
Paul Shore \\ University of Regina, Regina, Canada \\ ShoreP@BrandonU.CA \\ Péter Tusor \\ Péter Pázmány Catholic University, Budapest, Hungary \\ tusor@btk.ppke.hu
}

\begin{abstract}
Péter Pázmány (1570-1636) was one of the most significant personalities in early modern Hungarian history. Born a Protestant, Pázmány converted to Catholicism while a student and then became a Jesuit. Despite the Society's requirement of vows from its members that excluded the possibility of holding high ecclesiastical office, Pázmány became provost of Turóc (a small church benefice in northern Hungary) and shortly thereafter archbishop of Esztergom and primate of Hungary. His tenure was marked by ecclesiastical reform and multiple educational projects of which the most notable was the founding of a university in Nagyszombat (Trnava). He was also the author of influential devotional and polemical works in the Hungarian vernacular. Pázmány's legacy as a preserver and promoter of a "civilization" and a creed both Christian and European and of a culture distinctly Hungarian endures, as does his reputation as a master and shaper of Hungarian prose.
\end{abstract}

\section{Keywords}

confessional identity - Counter-Reformation - Habsburg - Hungary - Jesuits Pázmány - Primate - University of Nagyszombat (Trnava) 
Péter Pázmány de Panasz was arguably one of the most influential personalities in early seventeenth-century Hungary, and a major figure in Catholic post-Tridentine Europe. ${ }^{2}$ In an era when the influence of the Society of Jesus was at its peak and when Jesuit-trained orators and polemicists were widely prominent, Pázmány nonetheless stood out, both as a Jesuit and later as archbishop and cardinal. Born in 1570 to Miklós Pázmány and Margit Massai, ${ }^{3}$ both of Calvinist noble families of Bihar County, with two residences: in a little village Panasz close to Várad and in the city; this is geographically Hungary but belonged to the Principality of Transylvania. He was sent to the Jesuit collegium in Kolozsvár (Cluj, Clausenburg) at thirteen, converted to Catholicism in his early teens and joined the Society in Kolozsvár at the age of eighteen. ${ }^{4}$ Years later, during his examination for the post of cardinal, Pázmány asserted,

1 Thanks to Lynn Whidden for support in completing this project.

2 Among the most important works relating to Pázmány are Petri Pázmány... opera omnia. Pázmány Péter... Összes munkái I-VII, ed. Demkó György-Rapaics Rajmund et al. (Budapest: Typis Regiae Scientiarum Universitatis, 1894-1905); Petri... Pázmány epistolae collectae. Pázmány Péter... összegyüjtött levelei I-II, ed. Hanuy Ferenc (Budapest: Typis Regiae Scientarum Universitatis, 1910-11), http://www.ppek.hu/konyvek/Pazmany_Peter_Osszegyujtott _Levelei_I_kotet_Facsimile.pdf and http://www.ppek.hu/konyvek/Pazmany_Peter _Osszegyujtott_Levelei_II_kotet_Facsimile.pdf (accessed February 6, 2020).

Among the most useful new bibliographies of his works, documents, and the entire secondary literature are Adonyi Judit and Maczák Ibolya, Pázmány Péter-bibliográfia 1598-2004 (Piliscsaba: Pázmány Péter Katolikus Egyetem, Bölcsészettudományi Kar, 2005); Hargittay Emil and Maczák Ibolya, "Pótlások a Pázmány Péter-bibliográfiához, Balázs Mihály köszöntése," Acta historiae litterarum Hungaricarum Universitatis Szegediensis 30 (2011): 160-83. In addition, we note his papers in the Primatial Archives in Esztergom: Archivum Primatiale (Esztergom), Archivum Ecclesiasticum Vetus, especially, n. 134-99 and 2124 and Archivum Primatiale (Esztergom), Archivum Saeculare, Acta Radicalia et Protocollaria, especially Classis V and Classis X; Prot. G.

3 For a recent study and genealogy of the origin of the family, see Tusor Péter, Kánoni kivizsgálás Pázmány Péterröl: A Pázmány-Tholdy-archívum irataival (= Collectanea Vaticana Hungariae II/6) (Budapest-Rome: Gondolat Publishing House, 2017), 419-56, http://institutumfraknoi .hu/kanoni_kivizsgalas_pazmany_peterrol_csaladja_katolizalasa_misszionalasa_pazmany_ tholdy_archivum (accessed February 9, 2020),

4 Here the linguistically gifted Pázmány acquired a knowledge of Polish (although there is no evidence that he ever used it). Pázmány's mastery of Italian is documented in his notes. Tusor Péter, "Pázmány Péter esztergomi érsek levelei Rambaldo Collaltóhoz (1621-1626)," Lymbus (2003): 111-16, http://epa.oszk.hu/01500/01500/oooo1/pdf/Tusor_Peter.pdf (accessed February 6, 2020). For details of this period in Pázmány's life, see Őry Miklós, S.J., Pázmány Péter tanulmányi évei (= Pázmány Irodalmi Mühely. Tanulmányok 5) (Piliscsaba: Pázmány Péter Katolikus Egyetem, Bölcsészettudományi kar, 2006) and Őry Miklós and Szabó Ferenc: Pázmány Péter, Válogatás müveiből (Budapest: Szent István Társulat, 1983), 11-107. 
"Although all my ancestors were Catholics, my father and mother in their youth were led astray by their heretic kin and — proh dolor-died as heretics." ${ }^{5}$ One biographer has characterized the future cardinal's personality as "extroverted"; undoubtedly, he was energetic and ambitious. ${ }^{6}$ Next came the study of philosophy in Vienna (1590-93) where he developed a friendship with Wilhelm Lamormain (1570-1648) who later became confessor to Ferdinand II (r.161937). ${ }^{7}$ Pázmány spent his novitiate in Kraków and Jaroslav, from 1588 until 1590, and before his sojourn in Vienna, followed by theological studies in Rome. In 1596, Pázmány was ordained priest in Rome, becoming a professor of philosophy in Graz in $1597 .^{8}$ Pázmány's orientation in these early years was influenced by the dominant power of the House of Austria in Central Europe, but his rise had been preceded by a decline in the level of cooperation between the Habsburgs and the papacy, a trend that had vast consequences for Hungary. ${ }^{9}$ At the same time, the connection between Graz in Inner Austria, ruled by the Habsburgs, and Hungary remained highly significant for the Society of Jesus: between 1586 and 1640, four hundred Hungarian Jesuits matriculated at Graz, making the university the most important staging point for Jesuit activities in the Habsburg East. ${ }^{10}$ Pázmány returned twice to teach in Graz, lecturing in philosophy between 1597 and 1600 and in theology from 1604 to 1607 , and he

5 Cited in Tusor Péter, "Péter Pázmány processus inquisitionisa az Aldobrandini hercegek frascati levéltárában," Egyháztörténeti Szemle 4, no. 1 (2003): 3-21, at 19.

6 Fiore Mester, “Simplicity’ and Extroversion in Cardinal Péter Pázmány’s (1570-1637): Search for Ultimate Reality and Meaning," Ultimate Reality and Meaning 22 (1999): 189207, at 189 (accessed February 6, 2020).

Varsányi Orsolya, “Appendix: A Mahomet vallása hamisságárul," in Pázmány Péter: Tíz bizonyság, 1605;Jegyzetek a szövegkiadáshoz, ed. Ajkay Alinka (Budapest: Universitas Kiadó, 2012), 364-73, at 372 .

8 Paul Richard Blum, Studies on Early Modern Aristotelianism (Leiden: Brill, 2012), 51; Péter Tusor, Péter Pázmány's Process of Inquiry: His Family, Catholicization, Missions (Budapest/ Rome: MTA-PPKE Vilmos Fraknói Vatican Historical Research Group, 2017). Fraknói Vilmos, Pázmány Peter és kora, 3 vols. (Pest: M. Ráth, 1868-72). For Pázmány's lectures in Graz that included the natural sciences, with particular focus on Aristotle's Meteorologica, see "Lucian Petrescu, Meteors and Mixtures: Problems of Hylomorphic Composition in Aristotelian Natural Philosophy" (PhD diss. Ghent University, 2014), 107-38, https://biblio. ugent.be/publication/8504510/file/8504511.pdf (accessed February 5, 2020). Thomas Aquinas and Averroes also figure in these lectures. See Petri Cardinalis Pázmány... Opera omnia, vol. 2: Physica (Budapest: Typis Regiae Universitatis, 1895), 7. In addition, the young professor taught “dialectica," or the art of debate. See Fraknói, Pázmány Péter, 1:15. Péter Tusor, Papal Consistories and Hungary in the $15^{\text {th }}-16^{\text {th }}$ Centuries (Budapest/Rome: MTA-PPKE "Lendület" Egyháztörténeti Kutatócsoport, Gondolat, 2012), 95.

10 Henry Linz, "The German Cultural Influence in Hungary before the Eighteenth Century" (PhD diss., The Ohio State University, 1967), 211. 
modelled the new university in Nagyszombat (Trnava) on Graz and brought many professors to Hungary from there. ${ }^{11}$

The Habsburg-dominated world in which the young convert began his climb in the Catholic hierarchy was one in which the church was in a noticeably weak position. Even after scoring some successes in converting members of the nobility, the church in 1610 could claim only one in five among the nobility of Bohemia, and one in ten of the nobility of Upper Austria. ${ }^{2}$ The numbers for Royal Hungary were similar, where entire districts had ceased to possess any significant Catholic population. The reality that despite the reforms of the Council of Trent (1545-63), the Catholic position in Central Europe had remained very weak for decades must be kept in mind when assessing both Pázmány's achievements and the responses of his contemporaries to these achievements. He often was compelled to initiate projects from a defensive position and with scant resources and few allies at hand his situation was not improved by the outbreak of the Thirty Years' War (1618-48), which although it was not fought in Hungary, caused great destruction of Habsburg assets and continued through the final nineteen years of Pázmány's life. Thus, a tension exists between the triumphalist tone of Jesuit self-representation in the first decades of the seventeenth century and the frequently difficult if not desperate circumstances in which Jesuits, including Pázmány, labored in regions east of the Leitha. These tensions continued after Pázmány became a cardinal and have contributed to his posthumous reputation as a Catholic hero laboring under adverse conditions. Catholic writers appropriated his story, thereby continuing a triumphalist narrative while acknowledging the difficulties under which he worked. ${ }^{13}$

Pázmány's contributions to the development of the Hungarian language extended to translations made into Hungarian. His rendering of the Imitatio Christi from the Latin of Thomas a Kempis (1380-1471) was an important vernacular translation of that work. ${ }^{14}$ To Pázmány likewise belongs the credit for pushing through authorization of a Hungarian translation made from the

\footnotetext{
11 For Pázmány as theologian, see Szabó Ferenc, Krisztus és egyháza Pázmány Péter életmüvében (Isten és tudomány-Pázmány Irodalmi Mühely, Tanulmányok 11) (Budapest: Jézus Társasága Magyarországi Rendtartománya-L'Harmattan, 2012).

12 Peter H. Wilson, The Thirty Years' War: Europe's Tragedy (Cambridge, MA: The Belknap Press of Harvard University Press, 2009), 74.

13 For example, Matthias Tanner, Societas Jesu Apostolorum imitatrix ... pars prima: Societatis Jesu Europece (Prague: Typis Universitatis Carlo-Ferdinandeæ, 1694), 670.

14 Kempis Tamásnak Krisztus követésérül négy könyvei (Vienna, 1604).
} 
Vulgate by his Jesuit protégé Georgius Káldi $\left(1573^{-1634)} \cdot{ }^{15}\right.$ The cardinal also left his mark on liturgy not only in the Hungarian, but also in the German and Slavic languages, reissuing the Latin Rituale Strigoniense ${ }^{16}$ which contains the earliest example of the Slavic language spoken in Upper Hungary, in $1625 \cdot{ }^{17}$ Yet, Pázmány's Hungarian writings did not enjoy universal approval, even among his fellow Jesuits; his huge posthumous reputation, which extended into folk culture, ${ }^{18}$ somewhat obscures the fact that in his own day he was often controversial. ${ }^{19}$

\section{Ascent}

A quarrel with a fellow Jesuit resulted in Pázmány being summoned once to Rome to defend his theological views; he was cleared. ${ }^{20}$ The rising scholar earned his doctorate in 1605, having had Robert Bellarmine (1542-1621) as a mentor. The following year, he published perhaps his most influential work,

15 This did not take place until 1625. Molnár Antal, "A horvát és magyar katolikus bibliafordítás és a római inkvizíció," Magyar Könyvszemle 119, no. 1 (2002): 24-37, at 31.

16 The complete title is Rituale Strigoniense, seu formula agendorum in administratione sacramentorum ac ceteris Ecclesice publicis functionibus. The introduction explains how the antecedents of this document were prepared by Nicholas Oláh (1493-1568, archbishop of Esztergom 1553-68) in 1560 and further developed by Nicholas Telegdi (1535-86; primate and archbishop of Esztergom 1580-86), in 1586. See Varga Benjámin, Magyarországi rituálék az újkorban, 1625-től Szakdolgozat (Budapest: Eötvös Loránd Tudományegyetem Bölcsészettudományi Kar, 2012), 13-14, http://vallastudomany.elte.hu/sites/default/files/ Publika\%CC\%81cio\%CC\%81k/VB/Magyarorszagi_ritualek_az_ujkorban_1625-.pdf (accessed February 7, 2020).

17 Andrej Krivda, Il rituale Strigoniense (1625) e le sue due fonti: Ordo et ritus (1560) e Agendarius (1583) (Rome: Lozzi, 2012), 50.

18 Pázmány was even credited with cures for various ailments that found their way into popular recipe collections. See Tünde Lengyelová, “The Mystery of Birth: Magic, Empirical and Rational Approaches to Women's Medicine in the Medieval and Early Modern Periods," in The Role of Magic in the Past, ed. Blanka Szeghyová (Bratislava: Pro Historia, 2005), 117-36, at 121.

19 Palatine Nicholas Eszterházy (in office 1625-45), a convert to Catholicism, denounced Pázmány's building projects as wasteful and self-worshipping. Danica Stojkovičová and Zuzana Ludiková, "Notes about Conservation Treatment of the Early Baroque High Altar of the Assumption of the Virgin Mary in Domaniža," in Acta Artis Academica, ed. David Hradil and Janka Hradilová (Prague: Akademie výtvarných umění v Praze, 2014), 181-93, at 182.

20 Rona Johnston, Howard Louthan, and Tadhg Ó hAnnracháin, "Catholic Reformers: Stanislas Hosius, Melchior Khlesl, and Péter Pázmány," in A Companion to the Reformation in Central Europe, ed. Howard Louthan and Graeme Murdock (Leiden: Brill, 2015), 195-222, at 212 . 
Keresztényi Imádságos könyv, a "Book of Hours," which went through thirty printings by the end of the nineteenth century. ${ }^{21}$ Pázmány professed his four vows in Graz in 1607.22 After his ordination in 1596, Pázmány returned to Rome twice more, once from December of 1614 until January of 1615 and again in the spring of 1632 .

Pázmány worked in Vágsellye (Šal'a, Schelle) and Kassa (Košice, Kaschau) in the mountainous part of Hungary ruled by the Habsburgs from 1601 to $1603^{23}$ and from 1607 to 1615 was in the court of Cardinal-Primate Ferenc Forgách (in office 1607-15), his confessor and counselor. ${ }^{24}$ However, he was required to travel once more to Rome, where between December 15, 1614 and January 24, 1615 he defended himself against accusations of sexual misconduct having secret relation with a noble woman. Once cleared, Pázmány's assignment was to return to Hungary and to bring order and discipline to a Catholic clergy demoralized by the collapse of the Hungarian Kingdom: reflecting the dictates of the Council of Trent, he required celibacy ${ }^{25}$ and high educational attainment from all clergy. Pázmány was also determined to recover properties lost to the church during the decades of turmoil preceding his appointment. ${ }^{26}$ In this and in all of his subsequent undertakings, Pázmány stressed the Tridentine unity of the Catholic Church and its indivisible connection to the House of Habsburg. ${ }^{27}$ This drive for unity extended to plainchant, which the cardinal also reformed, introducing throughout the land the reformed Roman rite and chant endorsed

21 Bogár Judit, “Pázmány Péter Imádságos könyvének kiadásai és a reprezentáció," in Egyház és reprezentáció a régi Magyarországon, ed. Orsolya Báthory and Franciska Kónya (Budapest: $M T A-P P K E$ Barokk Irodalom és Lelkiség Kutatócsoport, 2016), 59-77.

22 Cf. Hanuy, ed., Pázmány epistolae collectae, 1:20-21.

23 Paul Richard Blum, "Peter Pazmany SJ als Grazer Philosophieprofessor," Semiotische Berichte 1, no. 2 (1998): 57-74, at 68-69; Jezsuita okmánytár, ed. Mihály Balázs et al. (Szeged: József Attila Tudományegyetem, 1995), 30.

24 Fraknói, Pázmány Peter, 3:335.

25 Pázmány's principal weapon against concubinage was a visitation protocol established in 1616. See István Monok, "Die Pfarreien im Karpatenraum und ihr Buchbesitz in der Frühen Neuzeit," in Kultur und Literatur der Frühen Neuzeit im Donau-Karpatenraum: Transregionale Bedeutung und eigene Identität, Acta Germanica, 14 (Szeged: Grimm, 2014), 30130, at 326. Pázmány's canonical visitations appear in Pázmány Péter egyházlátogatási jegyzőkönyvei (1616-1637), ed. Beke Margit, Strigonium Antiquum, 3 (Budapest: Márton Áron, 1994).

26 István György Tóth, "Old and New Faith in Hungary, Turkish Hungary and Transylvania," A Companion to the Reformation World, ed. R. Po-chia Hsia (Oxford: Blackwell, 2004), 20520, at 214-15.

27 Hughes Oliphant Old, The Reading and Preaching of the Scriptures in the Worship of the Christian Church, vol. 5: Modernism, Pietism, and Awakening (Grand Rapids: Eerdmans, 2004), 316-17. 
by the Council of Trent. ${ }^{28}$ Liturgical reform was in fact so important to Pázmány that it featured in all four councils and synods that he convened to impose Tridentine reform: in Pozsony (Bratislava, Pressburg) in 1628, 1629, 1630 (at which the Roman missal replaced that of Esztergom), and in 1633 in Nagyszombat (Trnava). An additional synod held in Jászó (Jazov, Jaussau) in 1635 was convened by the then bishop of Eger and later archbishop of Esztergom Lósy Imre (c.1580-1642; in office $1637-42) .{ }^{29}$

The development of this theme required Pázmány to regard Western Europe as, if not fundamentally more "civilized," at least the source of doctrine and language that could restore peace and doctrinal conformity to a region overrun by "infidels" and "infected" with "heretical" ideas. We find a hint of this positive regard of the West in the addition that Pázmány probably made for his nephew's library: De l'usage des passions (1641) by the Oratorian Jean-François Senault (1599-1672). ${ }^{30}$ Not only is this work in a Western European vernacular, but it would later be cited with approval by French Jansenists. Pázmány's Graz lectures on Aristotle show an even stronger connection to developments in Western medicine: Andreas Vesalius (1514-64), French physician Jean-François Fernel (1499-1557), and Cristóbal de Vega (c.1510-73) physician to Don Carlos (1545-68), prince of Asturias, are all cited. ${ }^{31}$ While acknowledging these personalities might not seem unusual from a modern perspective, Jesuit universities did not typically include faculties of medicine and few Jesuit priests were physicians. Indeed, the $1586 \mathrm{draft}$ of the Ratio studiorum prohibited digressions on medical topics (although this rule was not always observed).

The perilous position of the Catholic Church in Hungary, where the Peace of Vienna (1606) had granted freedom of religion, ${ }^{32}$ called for exceptional action by the papacy. Paul V (r.1605-21) therefore relieved Pázmány of his vow as a Jesuit that prevented him from accepting a high position in the Catholic

28 Gabriella Gilányi, "The Reception of Post-Tridentine Cantus Romanus in 17th- and 18thCentury Hungary," Studia musicologica 50, nos. 3/4 (2009): 301-14, at 301.

29 Carolus Péterffy, Sacra Concilia Ecclesiae Romano-catholicae in Regno Hungariae celebrata..., 2 vols. (Posonii [Bratislava]: Typis haeredum Royerianorum, 1742), 2:228-333.

30 István Monok, "La présence des auteurs français dans les lectures de la noblesse hongroise," Cahiers d'études hongroises 7 (1995): 38-50, at 47.

31 Paul Richard Blum, "Péter Pázmánys Seelenlehre," in Pázmány Nyomában: Tanulmányok Hargittay Emil tiszteletére (Vác: Mondat, 2013), 87-94, at 89.

32 Péter Tusor, “Dynastic Politics, Diplomacy, and the Catholic Church: Péter Pázmány's 1616 Appointment as Archbishop of Esztergom," in A Divided Hungary in Europe: Exchanges, Networks and Representations (1541-1699), vol. 1: Study Tours and Intellectual-Religious Relationships, ed. Gábor Almási, Szymon Brzeziński, and Ildikó Horn (Newcastle upon Tyne: Cambridge Scholars, 2014), 149-81, at 155. Considerable freedom of religious practice had already been granted in Transylvania. 
hierarchy. ${ }^{33}$ Succeeding Cardinal Ferenc Forgách (1560-1615), also a convert from Protestantism and for whom he had served as confessor, Pázmány simultaneously became archbishop of Esztergom and primate of Hungary, until his death, holding his seat in Nagyszombat (Trnava) in modern day Slovakia since Esztergom remained under Ottoman control. ${ }^{34}$ In 1616, Pázmány first was appointed provost (praepositus) of Turócz by the emperor and king Matthias II with the approval of the pope, ${ }^{35}$ but not before he was cleared of the charge of having fathered a child. ${ }^{36}$ Pázmány meanwhile underwent a brief and temporary status as a monk in the Somascan order. ${ }^{37}$ The move was largely symbolic, as it circumvented the difficulties created by a Hungarian law preventing any Jesuit from owning any landed property, thereby enabling Pázmány to become primate. Of equal significance was the vow Pázmány had professed as a Jesuit never to accept any ecclesiastical dignity. Indeed, Rome was well aware of the risks involved in violating the well-known position of the Society regarding the elevation of one of its own to the archbishopric. Many years after the fact, Superior General Muzio Vitelleschi (in office 1615-45) argued that Pázmány's release from his vows had been done for the "salvation of the Kingdom of Hungary," yet his appointment did the Society no harm and probably enhanced its prestige. ${ }^{38}$ The deal was accomplished through the efforts of the papal nuncio, Placido de Mara (1608-16) and Melchior Klesl, cardinal and imperial chief minister. Pázmány's principal rival for the position had been Demeter Náprágyi (1564-1619), an outstanding writer and lover of art. However, Náprágyi was a figure more in tune with the humanistic culture of the previous century and

33 At the time of their final profession, Jesuits must undertake a vow never to "strive or ambition, not even indirectly, to be chosen or promoted to any prelacy or dignity in or outside the Society" (Constitutions, Part X, no. 6 [817]).

34 Tusor Péter, Pázmány, A Jezsuita érsek (Budapest/Rome: MTA-PPKE “Lendület" Egyháztörténeti Kutatócsoport, 2016).

35 László Lukács and Ferenc Szabó, “Autour de la nomination de Péter Pázmány au siège primatial d'Esztergom (1614-1616): Pázmány est-il resté jésuite après sa nomination?," Archivum historicum Societatis Iesu 54 (1985): 77-148, at 99.

36 Tusor, Pázmány, 368; Robert Bireley, Religion and Politics in the Age of the Counterreformation: Emperor Ferdinand ii, William Lamormaini, SJ, and the Formation of Imperial Policy (Chapel Hill: University of North Carolina Press, 1981), 29.

37 Tusor Péter, “A legkorábbi Pázmány-portré 'rejtélye," Mưvészettörténeti Értesítő 62, no. 2 (2013): 303-10. Documents relating to Pázmány's entrance into the order are found in Sávai János, “Pázmány és a szomaszkok: A szomaszkok genovai levéltárának dokumentumai," Lymbus 4 (1992): 123-41, at 129-40.

38 Lukács László, “Jezsuita maradt-e Pázmány mint érsek?," in Pázmány Péter emlékezete halálának 350 évfordulóján, ed. László Lukács and Ferenc Szabó (Rome: Prugg Verlag, 1987), doc. no. 24 . 
thus had little chance of winning a position so closely tied to the power politics of the Counter-Reformation.

Two years later, Pázmány proved his loyalty to the House of Habsburg and his skill by convincing the Hungarian diet to elect Ferdinand, archduke of Austria, a king. The environment in which the archbishop worked remained turbulent: the incursions of Gabriel Bethlen (prince of Transylvania 1613-29) in 1619-21 compelled Pázmány to seek refuge in Vienna. ${ }^{39}$

\section{The Man of Letters}

Living in an age that greatly valued oratory, Pázmány's skills were renowned and he has been called an "artist of the Hungarian language." 40 He was also the dominant Hungarian literary personality of his day. Pázmány's first important work in vernacular was Felelet Magyary Istvánnak (Answer to István Magyari), a response to the charge by a Lutheran pastor that Catholicism was the cause of the disastrous state into which Hungary had fallen. ${ }^{41}$ Among Pázmány's works, his rebuttal to the Reformed pastor Peter Alvinczi (1570-1634, a Calvinist pastor in Kassa) is regarded as a landmark of Hungarian prose. ${ }^{42}$ The same year that this polemical piece appeared, Pázmány also published Öt szép levél (Five beautiful letters), also written against Alvinczi, in which the Catholic doctrine of grace is expounded. ${ }^{43}$ The cardinal's quarrels with Lutheran clergy took a somewhat similar form. Writing in Latin under the pseudonym Joannes Jemicius, ${ }^{44}$ with the identity of a parish priest in Šenkvice (Senkőc), Pázmány in 1610 began a polemical debate with Lutherans who had objected to an attack by Primate Forgách on the Synod of Zsolna, which had set up a structure for the Evangelical Church. ${ }^{45}$ The Lutherans responded in kind, and Pázmány's

39 Géza Pálffy and Alan Campbell, "Crisis in the Habsburg Monarchy and Hungary, 16191622: The Hungarian Estates and Gábor Bethlen," The Hungarian Historical Review 2, no. 4 (2013): 733-6o, at 737 .

40 Joseph Reményi, Hungarian Literature (Washington, DC: American Hungarian Federation, 1946 [?]), 15 .

41 Felelet az Magiari Istvan sarvari praedikatornak az orzag romlasa okairul irt könivere (Nagyszombat [Trnava]: Typ. Capituli Strigoniensis, 1603).

42 Alvinczi Peternek sok tetovazo kerengesekkel es ceghéres gyalazatokkal... ([Bratislava?], 1609).

43 Pál Ács, Reformations in Hungary in the Age of the Ottoman Conquest (Göttingen: Vandenhoeck and Ruprecht, 2019), 255.

44 Jemicius may have been a historical person. Pázmány Péter: Ismeretlen magyar könyve; Okok, nem okok, ed. Stripsky Hiador (Budapest: Pázmány Egyetemi Könyvsajtójában, 1937), 16.

45 Peniculus Papporum Apologiae Solnensis Conciliabuli... (Posonii [Bratislava]: In Aula Archiepiscopali, 1610). 
rejoinder, written under the same pseudonym, is filled with learned and inkhorn terms by which he seeks to demolish his opponents. ${ }^{46}$

Four years later, using a new pseudonym, Lethenyei István, which alludes to an actual location in Hungary, Pázmány launched another attack on the Reformed pastor. ${ }^{47}$ His criticism of the Cambridge Puritan divine William Whitaker (1548-95) demonstrates the breadth of Pázmány's reading in contemporaneous polemical literature. ${ }^{48}$ His Dissertatio an vnvm aliquid ex omnibus Lvtheranis dogmatibvs... (Posonii, 1631), was a response to Ján Hodík (15851642), the Lutheran superintendent of Trencsény county (1619-42). While a number of his theological opponents had Slovak origins and Pázmány took evident pride in wielding his native tongue as a rhetorical weapon in ways that have been called "waspishly funny," the reader finds no trace of ethnic bias in his works. ${ }^{49}$

Probably Pázmány's most influential work was the massive Igazságra vezérlo" Kalauz (Guide to divine truth), which first appeared in 1613 and went through successive revisions until his death. ${ }^{50}$ Kalauz showcased the cardinal's tactic of attacking Protestant confessions by using the writings of their own founders against them. ${ }^{51}$ Like Jesuits who in the coming century would promote the idea of Catholic continuity throughout Central Europe reaching back to the tenth century, Pázmány was at pains to show how the social and ecclesiastical organization of the kingdom could be traced to its consecration by the "Proto-Rex" St. Stephen (r.1001-38) and had continued "non interruptus" (without interruption). ${ }^{52}$

In this, Pázmány was a precursor of later Hungarian Jesuits who would promote the idea of the continuity of the "Apostolic Kingdom" and its role as an

46 Logi Alogi Quibus Baptae Calamosphactae Peniculum Papporum Solnensis... (Bratislava, 1612).

47 Csepregi mesterség: Calvinista tükör; Az igazságnak gyözedelme (Vienna, 1614). Some sources give Bratislava as the place of publication. Fraknói says no example was known to him. An edition was published in 1900.

48 Petri Pazmany diatriba theologica de visibili Christi in terris ecclesia (Graz, 1605).

49 However, in the margin of a work by William Whitaker Pázmány, writing of the "blindness and lameness" of Lutherans and Calvinists quoted the proverb, "A German cannot hide a limp or poverty." See Marta Špániová, "Katolícké bestsellery v literatúre 17. storočia: Z vydavatel'skej produkcie bratislavských typografov (1. čas)," Studia bibliographica Posoniensia 1 (2009): 27-49, at 37.

5o Hodoegus: Igazsagra vezerlő kalavz / mellyet irt, es most sok helyen jobbitván ki-bocsátott ... (Bratislava, 1637). This work has appeared in later editions, one as recent as in 2000. Hodoegus is a (slightly inaccurate) Latin rendering of a Greek word for "guide."

51 Graeme Murdock, "Reformed Orthodoxy in East-Central Europe," in A Companion to Reformed Orthodoxy, ed. Herman J. Selderhuis (Leiden: Brill, 2013), 293-321, at 311.

$5^{2}$ Vindiciae ecclesiasticae quibus edita a principe Bethlen in clerum Hungariae decreta ... (Vienna: Ex Officina Wolfgangi Schump, 1620), 10. 
incubator of a specifically Hungarian sanctitas (sanctity). But virtually any engagement with Hungarian history necessitated the addressing of the hardships that had befallen the kingdom since the appearance of the Ottomans. In his drawn-out debate with Alvinczi, Pázmány rejected the latter's claim that Ulászló I (1424-44; r.1440-44) had, by breaking his oath, incurred God's wrath and brought about the defeat of Varna. ${ }^{53}$ This was more that rhetorical point-scoring, for divine punishment was presented as an explanation of Hungary's woes by preachers of all stripes. ${ }^{54}$ Pázmány also addressed the claims of the Qur'an and thus the presence of a Muslim population deep inside his home country in Az Mostan Tamat Vy Tudomaniok Hamissaganak Tiiz Nilvan Valo Bizonisaga (Ten plausible proofs for the falsity of some recently emerged doctrines) (Graz: Georg Widmanstetter, 1605), although lurking behind this antiQur'anic polemic was a deeper concern at the rapid expansion of Unitarianism in Transylvania. ${ }^{55}$

Taken together, Pázmány's publications, especially those in the vernacular have led some commentators to view his greatest contribution to Hungarian Catholicism as literary and intellectual rather than administrative or political. What give such a verdict power is the isolation of the Hungarian language from its immediate neighbors and the complicated emotions of pride and vulnerability fostered by this isolation. By using Hungarian as a rhetorical weapon, Pázmány took the language and by association, its speakers seriously. This gift to Hungarians was appreciated in his own day but became even more significant in later centuries when new blows would fall upon Hungary and many would turn to evidences of the historic nation's accomplishments and worth for solace. While it may be anachronistic to apply the term "entertainment" to many experiences in the seventeenth century, Pázmány's writings filled a role in an environment with few broadsides, as were found in German-speaking lands, and scant opportunities to encounter drama.

53 Hanna Orsolya Vincze, The Politics of Translation and Transmission: Basilikon Doron $n$ Hungarian Political Thought (Newcastle upon Tyne: Cambridge Scholars, 2012), 136.

54 Antal Molnár, "Struggle for the Chapel of Belgrade (1612-1643): Trade and Catholic Church in Ottoman Hungary," Acta Orientalia Academiae Scientiarum Hungaricae 6o, no. 1 (2007): 73-134, at 118.

55 Paul Shore, "Two Hungarian Jesuits and the Qur'an: Understanding, Misunderstanding, and Polemic," Journal of Qur'anic Studies 20, no. 3 (2018): 81-93, at 85-89. The modern meaning of scientia and its vernacular equivalents (including tudomány) did not existed in the early seventeenth century, the word meant "knowledge" both more broadly, and knowledge "of" something specifically —and it is as such that it made sense to apply it to the teaching of the Qur'an. 
Pázmány strove mightily to build and rebuild Catholic institutions, founding Jesuit schools at Pozsony (Bratislava, Preßburg) ${ }^{56}$ and Franciscan houses at Érsekújvár (now Nové Zámky) and Körmöcbánya (now Kremnica) (both now in Slovakia). Smaller parish churches were also established on his initiative. In Croatia, a part of Habsburg territories but and in union with Hungary, Pázmány used his influence to promote the career of Ivan Tomko Mrnavić (Marnavich Tomkó János, 1580-1637), titular bishop of Bosnia. ${ }^{57}$ The cardinal looked beyond Royal Hungary, noting that in eastern Transylvania the Observant Franciscan Cloister of Csíksomlyó (Şumuleu Ciuc) had fallen into disrepair but that it remained the "last bastion of Transylvanian Catholicism." Pázmány's entreaties to the Propaganda Fide in Rome were in this instance unsuccessful: the monks all died out, and the monastery was looted by locals who did not hesitate to help themselves to its wine. ${ }^{58}$ Pázmány had no better success in Belgrade, where Jesuits were locked in a dispute with Bosnian Franciscans. The secretary of the Propaganda Fide, Francesco Ingoli (1578-1649), disliked the Society and in 1632 the Jesuits were expelled from the city.

On November 19, 1629, Urban VIII (r.1623-44) created Pázmány cardinal. The gap of thirteen years between Pázmány's appointment as archbishop and his elevation to cardinal primate resulted from the need for a completely favorable set of external circumstances that finally coalesced in 1629 . Until the mid1620 s, the Habsburg cardinal nomination policy was shaped solely by imperial and Italian points of view, as well as by the individual ambitions of the nominated and self-promoting candidates. ${ }^{59}$ Pázmány's name only appears among the candidates after the appointment of Adalbert Harrach (1598-1667) as archbishop in Prague in 1626, quite possibly of the more stabilized situation in Habsburg Bohemia, and also because of Pázmány's services to the new king of Hungary, Ferdinand II. In addition, the Hungarian archbishop had a familiarity with the inner workings of the papal policy, namely Nuncio Carlo Carafa (162128) that his other rivals lacked. Pázmány had the support of his Jesuit colleagues,

$56 \quad$ Fraknói, Pázmány Péter, 2:242.

57 Daniel Premerl, "Zagreb Cathedral's Reliquary Bust of Saint Stephen the King: The Context of its Commission and its Attribution," Radovi Instituta za povijest umjetnosti 34 (2010): 101-12, at 108 .

58 István Keul, Early Modern Religious Communities in East-Central Europe (Leiden: Brill, 2009), 180-81; Galla Ferenc, Harminckilenc kiadatlan Pázmány-levél (Vác: Szerzői Kiadás, 1936), 114.

59 Tusor Péter, Purpura Pannonica: Az esztergomi “bíborosi szék" kialakulásának előzményei a 17. században (Budapest/Rome: Pázmány Péter Katolikus Egyetem, 2005), 86. 
but other potential obstacles had to be cleared away. Melchior Klesl (15521630), bishop of Vienna, had been Pázmány's mentor but had fallen in 1616 from favor with the Habsburgs after he had failed to control the rebellious Bohemian Estates, a development that might have been expected to damage Pázmány's prospects but that was more than counterbalanced by the archbishop's commitment to the course of the pope and the emperor. ${ }^{60}$ Pope Urban viII seemingly had no problem with Pázmány's earlier assertion that objections to Copernicus could not be derived from the Bible, although later he would condemn Galileo. ${ }^{61}$

Pázmány's achievements as a writer were strengthened by his recognized skill as a preacher. ${ }^{62}$ His sermons set forth logically a symbolic representation of the church as a force complementing the appropriate role of the Hungarian people (gens), an idea echoed in the charter of the University of Nagyszombat (Trnava), which was founded through the cardinal's efforts (and a contribution of one hundred florins) in 1635: "Qua ratione Catholicam Religionem in Hungaria propagare, et Nobilissimae Gentis Hungaricae dignitati consulere" (To propagate the Catholic faith in Hungary and to favor the dignity of the noble Hungarian nation). ${ }^{63}$

The new university, which like Graz had at the time only two faculties, Arts and Theology, because the nucleus of a Jesuit project that in the coming century would expand schooling and book culture across the Danube Basin. ${ }^{64}$ Yet,

6o Paul V had written, "certo anco amiano il padre Pasman." See Péter Tusor, "Dynastic Politics, Diplomacy, and the Catholic Church: Péter Pázmány's 1616 Appointment as Archbishop of Esztergom," in Divided Hungary in Europe, 149-81, at 174.

61 Jules Speller, Galileo's Inquisition Trial Revisited (Frankfurt am Main: Peter Lang, 2008), 78-79. Pázmány was well versed in the literature on Copernicanism, although he could of course not endorse the theory openly. Jolan Zemplén, "The Reception of Copernicanism in Hungary (A Contribution to the History of Natural Philosophy and Physics in the $17^{\text {th }}$ and $18^{\text {th }}$ Centuries)," in The Reception of Copernicus' Heliocentric Theory, ed. Jerzy Dobrzycki (Dordrecht: D. Reidl, 1972), 311-56, at 317.

62 For a sympathetic discussion of Pázmány as preacher, see Hugh Oliphant Old, The Reading and Preaching of the Scriptures in the Worship of the Christian Church, vol. 5: Moderatism, Pietism, and Awakening (Grand Rapids: Eerdmans, 2004), 316-22.

63 Charters of Foundation and Early Documents of the Universities of the Coimbra Group, $2^{\text {nd }}$ ed., Jos. M. M. Hermans and Mark Nelissen, eds. (Leuven: Leuven University Press, 2005), 35. To what degree "gens" in this context is identical with ethnicity in the modern sense is doubtful, yet significantly, Pázmány did not select the term "natio" which in this context refers specifically to the nobility.

64 Between 1603 and 1609, the archiepiscopal press in Nagyszombat (Trnava) produced Pázmány's earlier polemical writings. By 1623, a press had been established in Pozsony (Bratislava) under Jesuit direction. Gerald Sabo, Review of Dejiny jezuitov v Bratislave do roku 1773, by Jozef Hal'ko and Luboš Rojka, Journal of Jesuit Studies 3, no. 3 (2016): 546-48, at 547, doi: https://doi.org/10.1163/22141332-00303008-20 (accessed February 9, 2020). 
although Ferdinand II immediately offered his support, Urban VIII first did not provide confirmation of the status of the institution. ${ }^{65}$ This may have been because of tension between Pázmány and the powerful Barberinis; however, after what appears to have been a bureaucratic delay, papal approval was granted. ${ }^{66}$ The descendants of Pázmány's creation continue today, with the University of Nagyszombat (Trnava), Eötvös Loránd University, and Péter Pázmány Catholic University, each claiming a connection to the cardinal's creation. Pázmány spent significant amounts of money on the library he founded in Nagyszombat and that he enriched with a constant infusion of foreign publications. ${ }^{67}$

Had Pázmány been merely the founder of schools and a developer of curricula, he would still have cut a very large figure in Hungarian history. In 1624, he established a seminary in Vienna, the Pazmaneum, which still bears his name, for Hungarian priests entering the middle ranks of the church. ${ }^{68}$ Most importantly, Pázmány strove to recruit Hungarian pupils (including those who went to the Collegium Germanicum-Hungaricum in Rome), even paying their travel expenses and seeking leniency in admission standards for these students. Pázmány's sermon on the education of a Christian girl is of particular interest, both through his citing of Aristotle, he connects philosophy as established in nations ("az országok böcsületes állapotja") with female education, and because of an explicit reference to human sacrifice in the Old Testament, which Pázmány lays at the feet of "the Jews." ${ }^{\text {" } 9}$ Perhaps predictably, he advises girls to "stay at home, and if you need to go out, do so with your mother, and if you are among men, it should be as if you were among enemies, who would loot that most precious of treasures. ${ }^{70}$

65 Martyn Rady, Customary Law in Hungary: Courts, Texts, and the Tripartitum (Oxford: Oxford University Press, 2015), 160.

66 Pázmány's "quadriennalis relatio" to Urban viII, dated sometime after April 21, 1636, states "Aliud Seminarium Tyrnaviae curavit [...] ubi etiam novam ad benignam Sanctitatis Vestrte annuentiam, pro publico istius Regni bono et Religionis Catholicae incremento, erigit de facto Academiam... [Another seminary established in Nagyszombat [...] where for the common good of the kingdom and for the increment of the Catholic religion erected with the permission of Your Holiness a new academy as well]. Hanuy, Pázmány epistolae collectae, 2:770.

67 Julius Gyula Paulovits, “Foundation of the Eötvös Loránd University and Its History under Jesuit Administration, 1635-1773” (PhD diss., Iowa State University, 1977), 31.

68 For the history of the Pazmaneum, see Fazekas István and Beke Margit, $A$ bécsi Pázmáneum, ed. Zombori István (Budapest: METEM, 2002).

69 Mint kel a kerestzyén leányt nevelni preached on the twenty-third Sunday after Pentecost, http://sermones.elte.hu/?az=338tan_plaus_szaniko\#_ftn42 (accessed February 1, 2020).

70 "Otthon üljön, és ha a szükség kívánja, hogy kimenjen, anyjával menjen: és a férfiak között úgy légyen, mintha ellenségi között volna, kik legdrágább kincsétűl meg akarnák fosztani." 
The cardinal primate is renowned for having achieved many conversions among the high nobility of Hungary; this aspect of his career forms the core of the enduring Pázmány legend. ${ }^{71} \mathrm{He}$ has been called "the chief architect of the Catholic conversion model, ${ }^{72}$ an approach that went so far as to tailor an entire polemical work for the conversion of a specific aristocratic family. His longterm strategy included appointing custodians for the minor sons of a deceased aristocratic convert, thereby preventing any backsliding from the faith. ${ }^{73} \mathrm{He}$ could also weave flattery with warnings that approached threats in his correspondence with recent converts, as in the case of Ádám Batthányi (1610-59), who was rumored to have become Catholic merely for the sake of marriage. ${ }^{74}$ Yet these tactics did not always succeed. Pázmány's efforts to convert Péter Bethlen (?-1646), nephew of Prince Gábor Bethlen, foundered on the conflict between Péter's father István Bethlen (1582-1648) the Elder, who had turned to the Ottomans in his bid to be the next prince of Transylvania, and György Rákóczi (1630-48). ${ }^{75}$

Pázmány built Jesuit schools at Pozsony (Preßburg, Bratislava) ${ }^{76}$ and Franciscan houses at Érsekújvár (now Nové Zámky, where he also had an archiepiscopal palace constructed) and Körmöcbánya (now Kremnica) (both now in Slovakia). Before he died, Pázmány had taken the first steps to establish what would eventually become the University of Kassa (Košice) and was planning a separate see for Rozsnyó, Turóc, and Szepes a project that was not carried out for another 138 years. As primate Pázmány was also a great landowner whose projects impacted local economies. Planning the restoration of the Franciscan church and house in Érsekújvár, he ordered tens of thousands

71 For the social and political context of these conversions, see Tadhg Ó hAnnracháin, Catholic Europe, 1592-1648: Centre and Peripheries (Oxford: Oxford University Press, 2015), 123. While such conversions would be highly significant in any seventeenth-century European context, in Hungary, where, as Bitskey points out, feudalism was actually strengthening, making the importance of these shifts in religious affiliation even greater. Bitskey, "Collegium Germanicum Hungaricum," 117.

72 Gabriella Erdélyi, "Confessional Identity and Models of Aristocratic Conversion in Seventeenth- and Eighteenth-Century Hungary," Social History 40, no. 4 (2015): 474-96, at 476 .

73 Nataša Štefanec, "The Adaptable Religious Politics on the Zrinski Estates during the Reformation," in The Reformation in the Croatian Historical Lands: Research Results, Challenges, Perspectives, ed. Zrinka Blažević et al. (Zagreb: Biblijski Institut, 2015), 263-82, at 268n16.

74 Pázmány to Ádám Batthyány, March 25, 1630, cited in Erdélyi, "Confessional Identity," 48 on27.

75 Heltai János, "Bethlen Péter és Pázmány," in Az Országos Széchényi Könyvtár évkönyve 1982-1983 (Budapest: n.p., 1984), 411-21.

76 Peter Fedorčak, "Jesuit Mission in Košice and Circumstances of the Foundation of the University of Košice," Mesto a dejiny 3, no. 1, (2014): 49-55, at 50. 
of nails and hundredweights of iron bars from the craftsmen of Rozsnyó (Rožňava). ${ }^{77}$

Pázmány affected the Hungarian landscape in other ways. He required modifications in the construction of a Lutheran church in Pozsony, so that it was built without a tower or semicircular openings. ${ }^{78}$ Despite these very real achievements, Pázmány as a polemicist and theological writer possessed some significant limitations. His attacks on Calvinism, a confession for which he seemed to harbor a particular animus, could lack logical rigor and fairness, as when he dismissed vernacular translations of the Bible as unreliable. Yet as primate he was capable of countenancing compromise with Protestants in the face of the Ottoman threat. The cardinal was also very aware of theological developments further afield, and once expressed concern that the Catholic Church might become "deformed" so as to resemble the Anglican Church. ${ }^{79}$

Pázmány went to considerable lengths to remain a relatively independent figure in his dealings with the Holy See. His principal contact in Rome was Cornelius Heinrich Motmann (1589-1638), a judge of the Sacra Romana Rota, who communicated with him in code..$^{80}$ Occasionally, the cardinal clashed with Urban viII over Habsburg policy, as when in 1632 he tried unsuccessfully to persuade the pope to support the treaty binding Spain and the empire. ${ }^{81}$ The result was the Roman prevention of Pázmány's return as a permanent ambassador, or a cardinal protector. ${ }^{82}$ Worn out by his unsuccessful mission to Rome, Pázmány was in declining health the last six years of his life. He died on March 19, 1637 in Pozsony and was buried in St. Martin's Church in that

77 János Buza, "Crafts in Divided Ottoman-Era Hungary," in The History of Handicraft in Hungary, ed. János Szulovszky, trans. Alan Campbell, Mária Rita Máray, and Christopher Sullivan (Budapest: Hungarian Chamber of Commerce and Industry, 2012), 85-101, at 95.

78 János Krähling, "To the Methodology of Church Research in Hungary: Contributions to the Typology of $18^{\text {th }}$-Century Protestant Church Architecture," Periodica polytechnica 44, no. 1 (2013): $9^{-15}$, at 13 .

79 Pázmány to George Stobaeus, Vienna, September 26, 1607, in Epistolae, quae haberi poterant, S.R.E. Cardinalis, archi-episcopi Strigoniensis, et Hungariae primatis, Petri Pázmány, ed. Jakob Ferdinánd Miller (Buda: Typis Regiae Universitatis Hungaricae, 1882), 9. Stobaeus, the prince-bishop of Lavant, was a former classmate of Pázmány. See Benda Kálmán, "Pázmány Péter politikai pályakezdése," Az MTA I. osztályának közleményei 28 (1979): $275^{-87}$, at 276 .

80 Péter Tusor, "Pázmány bíboros olasz rejtjelkulcsa: C. H. Motmann 'Residente d'Ungheria' (A római magyar agenzia történetéhez)," Hadtörténelmi Közlemények 116, no. 2 (2003): $535^{-81 .}$

81 Robert Bireley, Ferdinand II, Counter-Reformation Emperor, 1578-1637 (Cambridge: Cambridge University Press, 2014), 241.

82 Péter Tusor, "Episcopalist Crisis in the Hungarian Episcopate (1639)," in Il papato e le chiese locali, ed. Péter Tusor and Matteo Sanfilippo (Viterbo: Sette Città, 2014), 147-66. 
city. ${ }^{83}$ Since the cardinal had been released from his vow of poverty, he was able to compose a will that named, among others, his nephew Nicolaus (1622after 1662 ) as a beneficiary. ${ }^{84}$

Beyond his very real accomplishments, Pázmány remains significant as a symbol of both the Catholic identity of Hungary and, more broadly, of a highly developed Hungarian-language literary culture, a distinction further highlighted by the decline (with the important exception of Transylvania) of that culture in the ensuing century. While he was not the sole impetus for the standardization and modernization of the Hungarian language, the freshness of Pázmány's style and the wide readership that it gained greatly aided his contribution to this process. Less well known is Pázmány's contribution to the Vita Beati P. Ignatii Loiolae, written with Filippo Rinaldi (fl. c.160o-10) and Nicolas Lancicius ((1574-1653) (and possibly several others) and based on material in Pedro de Ribadeneyra's (1527-1611) biography. ${ }^{85}$

Tadhg Ó hAnnracháin points out that Pázmány saw himself as a synthesizer of ideas and was "no ivory-tower intellectual." 86 His continual and inevitable encounters with Protestants were one reason for this, but Pázmány was also the product of a Jesuit formation that, along with its arguably elitist components, also stressed public life and a vita activa, and promoting those who showed a capacity for both. Pázmány also embodied many of the features of the high Catholic baroque, as when he wrote to Urban viII seeking a plenary indulgence for the Church of St. Martin in Pozsony, owing to the presence there of relics of St. John the Merciful ( $f$ l. early seventh century) ${ }^{87}$ Yet, the cardinal did not blindly follow the baroque fashions of homiletics, and counselled his clergy against the use of obscure erudition and needless rhetorical

83 Recently Pázmány's tomb has been opened and the decomposition of his grave clothes studied. See Lucia Kraková, Katarína Chovanová, Maria Bučková, Andrea Puškarová, and Domenico Pangallo, "Disclosing a Crypt: Microbial Diversity and Degradation Activity of the Microflora Isolated from Funeral Clothes of Cardinal Péter Pázmány," Microbiological Research 168, no. 5 (2013): 289-99.

84 Jankovics József, "Pázmány Péter ismeretlen végrendelete 1637-ből," Lymbus 2 (2004): 61-69.

85 Vita beati P. Ignatii Loiole Societatis Iesv fundatoris (Rome, 1609).

86 Tadhg Ó hAnnracháin, "The Miraculous Mathematics of the World”: Proving the Existence of God in Cardinal Péter Pázmány's Kalauz," Studies in Church History 46 (2010): 248-59, at 250 .

87 Pázmány to Urban VIII, Rome, s.d., 1632, in Miller, ed., Epistolae, 124. 
flourishes so popular at the time. Indeed, the great theme of his ars praedicandi (art of preaching) was utilitas (utility). ${ }^{88}$ In his own sermons, Pázmány did not draw his images from the Spiritual Exercises of Ignatius of Loyola (c.1491-1556), nor did he emulate the style of his mentor Bellarmine, who piled up references from many disciplines to construct a theological argument. Instead, Pázmány was much indebted to the Spanish Jesuit Cypriano Soarez (1524-93), whose textbook formed the basis of his early training. Building on models of Cicero and Quintillian, Soarez advocated a pietas christiana (Christian piety) that might appeal to Protestants as well, while stating that "animis scripsi, non auribus" (I wrote for souls, not ears). To this Pázmány added a dose of day-to-day reality, ${ }^{89}$ while freely wielding terms as "atheist" and "pagan" in ways that today can look less than rigorous. In a kingdom, where despite the cardinal's efforts, a large portion—-perhaps even a majority—of the literate population remained Protestant, Pázmány's ability to address non-Catholics was one of his greatest strengths. ${ }^{90}$

At least one nineteenth-century Hungarian Calvinist writer asserted that "under Pázmány, the idea (eszme) of Hungary and of the Regnum Marianum were the same." ${ }^{11}$ While the historical accuracy of such a statement may be questioned, the association of Pázmány with a particular strain of Catholic devotion that emphasized the importance of the Kingdom of Hungary was very real, and has provided both Catholics and their opponents with a way of understanding the cardinal's mission as one that rose above merely dynastic considerations. Untangling Pázmány's hopes for a Hungary freed from Ottoman domination and reunited from his desire to see the church triumphant is not easy; perhaps the cardinal could not have done it himself. Likewise, his steadfast commitment to the advancement of the church cannot be easily uncoupled from a strong sense of self: his refusal to yield the place of highest honor to the Palatine at the coronation banquet of the queen of Hungary in 1622 can be seen of evidence of both.

88 István Bitskey, "Le Baroque édifiant dans l'œuvre d'un archevêque hongrois: Péter Pázmány," Baroque 8 (1976): 1-18, at 6, https://doi.org/10.400o/baroque.478 (accessed February 6,2020$)$.

89 Imre Bán, "Les variantes stylistiques de la prose baroque hongroise," Baroque 8 (2013): 1-8, at 2 .

9o In the following century, the Calvinist preacher Hermányi Dienes József used Pázmány's sermons. See Csilla Gábor, Doctrine-Virtue-Memory: Seventeenth-Century Hungarian Devotional Literature in European Context, trans. Emese G. Czintos, 40n18o, file://C:/Users/ Owner/Documents/DOCTRINE_VIRTUE_MEMORY.pdf. (accessed March 4, 2020).

91 Lajos Warga, A keresztyén egyház történelme, 2 vols. (Sárospatakon: Steinfeld B., 1887), 2:290. 
Pázmány's legacy as a preserver and promoter of a "civilization" and a creed both Christian and European and of a culture distinctly Hungarian may resist tight definition but remains part of his historical identity. At least one recent commentator has credited him with restoring a Hungarian "national consciousness." ${ }^{92}$ Already in the eighteenth century, as confessional hatreds began to ebb, some Hungarian Protestant writers could find positive aspects to his contributions, especially since he wrote in Hungarian..$^{93}$ In the twenty-first century, with phrases such as "Christian Europe" becoming part of political discourse in Hungary, ${ }^{94}$ the significance of this Jesuit cardinal may even grow in the years to come.

92 Márk Zsoldos, "Pázmány Péter als Leitfigur der Gegenreformation und der katholischen Wiedergeburt in Ungarn" (MPhil. thesis, University of Vienna, 2013), 57.

93 Bogár Judit, “Pázmány Péter alakja a 18. századi protestáns irodalomtörténet-írásban," in Pázmány nyomában: Tanulmányok Hargittay Emil tiszteletére, ed. Alinka Ajkay and Rita Bajáki (Vác: Mondat, 2013), 95-102, at 102.

94 Ishaan Tharoor, "Hungary's Leader Says He's Defending Christian Europe: The Pope Disagrees," The Washington Post (April 10, 2018), https://www.washingtonpost.com/news/ worldviews/wp/2018/04/10/the-popes-challenge-to-orban-and-europes-far-right/? noredirect=on\&utm_term=.1cde8f21b67e (accessed February 9, 2020). 